\title{
The State of Gender Representation in Physics in Federal College of Education, Pankshin-Nigeria
}

\author{
Macmillan Mafulul J osiah
}

\author{
Department of Physics \\ Federal College of Education Pankshin \\ Plateau State-Nigeria
}

Doi:10.5901/ ajis.2013.v2n10p93

\begin{abstract}
This paper delved into ascertaining the state of the art of gender representation in Physics in Federal College of Education, Pankshin-Nigeria. The data used in the study were obtained from admissions made into the Department of Physics in the College for the academic sessions $2008 / 2009$ to 2012/2013. A total of 257 samples were used and the simple percentage statistic was employed to analyze the data. The results revealed the persistence of female underachievement in Physics. Recommendations were proffered, which when followed, may reduce or eliminate female under-representation in Physics. Such recommendations included sensitizing parents and the Nigerian society on the need to desist from stereotyping and religious beliefs that are harmful to education.
\end{abstract}

Keywords: Gender, Representation, Physics, Federal College of Education, Pankshin-Nigeria.

\section{Introduction}

Gender, as defined by Merriam-Webster Incorporated (2006), is the behavioural, cultural, or psychological traits typically associated with one sex. In the context of this work, gender is a term employed to distinguish between male and female human beings based on their differing physiological structures. It has been documented that the female gender has been a victim of discrimination in all works of like. This discrimination has led to organizing conferences such as the World Summit for Children, New York in 1990, World Conference on Education for All (EFA) in 1990, the Pan-African Conference on Education of Girls (in Ouagadougou) in 1993 and the United Nations Conference on Women Development (in Beijing, China) in 1995 (Ogunleye-Adetona, 2003).

Gender discrimination manifests itself in varying faces. Some of these faces, as outlined by John and Davou (2008), include discrimination in profession. Women are always at the receiving end or discriminated against when it comes to issues of occupational choice. Ogunleye (2001) concurred that female students are unanimous in calling for Nigerian Government to provide equality of opportunities and job career prospects for the female gender to study Physics.

The importance of Physics as a requirement for the socio-economic development of any nation cannot be over-emphasized. Such a development hinges on scientific and technological development. Ogunleye (2001) is of the strong opinion that the technological potentials of any nation could be more accurately gauged by the quality of its Physics education, for without Physics, the technological culture of her citizens cannot be firmly rooted.

A mere observation of the female gender in science world-wide indicates a gross underrepresentation of women in science. In a study on the participation of women in science courses in Nigerian Colleges of Education, Oyedokun (2001) ascertained that only $25.95 \%$ of the total 1,029 students admitted to study Physics in the 1997/1998 academic session were female. In the 1998/1999 session, only 36.38\% of the total 962 students admitted to study Physics were female. 
Out of the 192 Physics lecturers in Colleges of Education in Nigeria during the 1997/1998 session, only $18(9.38 \%)$ of the lecturers were female. During the 1998/1999 session, a decrease in number of the female lecturers was observed even though there was a slight increase in the number of Physics lecturers in the Colleges. Only 15 (7.69\%) of the 195 Physics lectures were female.

In a study carried out by Trisma and Josiah (2008) on coping with gender inequality in academic achievement in Physics, it was revealed that only $20.83 \%$ of the total students admitted into Federal College of Education (FCE), Pankshin-Nigeria from 2000/2001 to 2004/2005 academic sessions to study Physics were female. This signifies female under-representation in Physics. Nsofor (2001) noted that a number of studies revealed that there are relatively few female students studying Physics in Nigerian schools. It is worthy of mention that the female students studying Physics achieve, on the average, significantly same as their male counterparts in post-secondary school level (Trisma and Josiah, 2008).

Regardless of the under-representation of the female gender in Physics in Nigeria, AfricanAmerican women found in Physics have immensely contributed to the scientific and technological growth of their nation. Deborah J. Jackson was involved in the development of photonic flight hardware for the Cassini space probe. Ann T. Nelms wrote a book that is used extensively by the Atomic Energy Commission to speed up its experiments. Rosa Clark Webster centered on optimizing the optical properties of ion-implanted gallium-arsenic-iridium light emitting diodes (LEDs); the photovoltaic properties of ion-implanted gallium-arsenic solar cells; and the electrooptical properties of $p-n$ junction devices. Shirley Ann Jackson was the first African-American woman to receive doctorate in Theoretical Physics from M.I.T. She was appointed chair of the Nuclear Regulatory Commission in 1995. (Bryant,Jnr \& Swinton, 2001). This is just but a mention of the African-American women contributing to the growth of science and technology through Physics.

Based on the afore-mentioned the researcher considered it important to conduct another study to ascertain the state of gender representation in Physics in recent years in Federal College of Education, Pankshin-Nigeria.

\section{Research Question}

The study attempted to find solution to the question: Has the gender gap existing in the Physics classroom situation in Nigeria been bridged?

\section{Methodology}

\subsection{Population and Sample}

The study population consisted of all the students admitted to study Physics at both the Nigerian Certificate in Education (NCE) and undergraduate (Degree) levels in Federal College of Education, Pankshin-Nigeria from 2008/2009 academic session to 2012/2013 academic session. A total of 257 students (comprising 193 male students and 64 female students) formed the population.

The population formed the sample.

\subsection{Instrumentation}

To gather data for the research question, the researcher interacted with the information files of the sample in the Department of Physics, Federal College of Education, Pankshin-Nigeria. Information on the number of male and female samples was obtained from the personal Department files of the sample. 


\subsection{Data and Method of Data Analysis}

The data used in the study were the number of male and female students at both the NCE and Degree level students for each academic session from 2008/2009 academic session to 2012/2013 academic session.

The simple percentage statistic was employed to analyze the data collected.

\section{Analysis of Data}

Table 1 shows the numbers and percentages of Physics students in both Degree and NCE programmes by gender in FCE Pankshin-Nigeria from 2008/2009 to 2012/2013 academic sessions.

Table 1: FCE, Pankshin-Nigeria: Statistics of Physics students' enrolments from 2008/2009 academic session to 2012/2013 academic session by gender.

\begin{tabular}{|c|c|c|c|}
\hline Academic & \multicolumn{2}{|c|}{ Gender } & \multirow{2}{*}{ Total } \\
\cline { 2 - 3 } Session & Male & Female & \\
\hline $2008 / 2009$ & $28(82.35 \%)$ & $6(17.65 \%)$ & 34 \\
$2009 / 2010$ & $34(66.67 \%)$ & $17(33.33 \%)$ & 51 \\
$2010 / 2011$ & $25(75.76 \%)$ & $8(24.24 \%)$ & 33 \\
$2011 / 2012$ & $54(72.00 \%)$ & $21(38.00 \%)$ & 75 \\
$2012 / 2013$ & $52(81.25 \%)$ & $12(18.75 \%)$ & 64 \\
\hline Grand Total & $193(75.10 \%)$ & $64(24.90 \%)$ & 257 \\
\hline
\end{tabular}

Table 2 indicates the numbers and percentages of Physics students in the Degree programme by gender in FCE, Pankshin-Nigeria from 2008/2009 academic session to 2012/2013 academic session.

Table 2: FCE, Pankshin-Nigeria: Statistics of Degree Physics students' enrolment from 2008/2009 academic session to 2012/2013 academic session by gender.

\begin{tabular}{|c|c|c|c|}
\hline Academic & \multicolumn{2}{|c|}{ Gender } & \multirow{2}{*}{ Total } \\
\cline { 2 - 3 } Session & Male & Female & \\
\hline $2008 / 2009$ & $7(100.00 \%)$ & $0(0.00 \%)$ & 7 \\
$2009 / 2010$ & $14(73.68 \%)$ & $5(26.32 \%)$ & 19 \\
$2010 / 2011$ & $12(92.31 \%)$ & $1(7.69 \%)$ & 13 \\
$2011 / 2012$ & $24(70.59 \%)$ & $10(29.41 \%)$ & 34 \\
$2012 / 2013$ & $15(88.24 \%)$ & $2(11.76 \%)$ & 17 \\
\hline Grand Total & $72(80.00 \%)$ & $18(20.00 \%)$ & 90 \\
\hline
\end{tabular}

Table 3 provides the numbers and percentages of Physics students in the NCE programme by gender in FCE, Pankshin-Nigeria from 2008/2009 academic session to 2012/2013 academic session.

Table 3: FCE, Pankshin-Nigeria: Statistics of NCE Physics students' enrolment from 2008/2009 academic session to 2012/2013 academic session by gender.

\begin{tabular}{|c|c|c|c|}
\hline Academic & \multicolumn{2}{|c|}{ Gender } & Total \\
\cline { 2 - 4 } Session & Male & Female & \\
\hline $2008 / 2009$ & $21(77.78 \%)$ & $6(22.22 \%)$ & 27 \\
$2009 / 2010$ & $20(62.50 \%)$ & $12(37.50 \%)$ & 32 \\
$2010 / 2011$ & $13(65.00 \%)$ & $7(35.00 \%)$ & 20 \\
$2011 / 2012$ & $30(73.17 \%)$ & $11(26.83 \%)$ & 41 \\
\hline
\end{tabular}




\section{Discussion}

\begin{tabular}{|c|c|c|c|}
\hline $2012 / 2013$ & $37(78.72 \%)$ & $10(21.28 \%)$ & 47 \\
\hline Grand Total & $121(72.46 \%)$ & $46(27.54 \%)$ & 167 \\
\hline
\end{tabular}

In an attempt to proffer solution to the research question raised, it was discovered that only $24.90 \%$ of the total students enrolled into Federal College of Education, Pankshin-Nigeria from 2008/2009 academic session to 2012/2013 academic session to study Physics were women (Table 1). From table 2, out of the 90 students enrolled into the Physics Degree programme of FCE, Pankshin-Nigeria from the 2008/2009 to 2012/2013 academic sessions only $18(20.00 \%)$ of the students were women. Table 3 revealed that only $27.54 \%$ of the 167 students enrolled into the NCE Physics programme of FCE, Pankshin-Nigeria from the 2008/2009 to 2012/2013 academic sessions represented the female gender.

The revelations signify female under-representation in Physics, a concurrence with earlier findings of Okeke (2001), Onwuakpa \& Akpan (2001) and Trisma \& Josiah (2008). Another revelation is that the female under-representation in Physics is persistent. This indicates that Nigeria has quite a long way to traverse toward the drastic reduction or elimination of the female gender under-representation in Physics. Possible explanations for the persistence in the female gender under-representation in Physics have been tendered by some researchers (Gonzuk \& Chagok, 2001; Ivowi \& Oludotun, 2001). Factors such as biological differences, religious beliefs and stereotyping are among many that are perceived to inhibit the female gender from studying Physics as a course.

Advances have been made on genetic deficits of the female gender. The generic deficits centre on biological components of the female as causal factors. However, according to Ibitoye (1998), in spite of the fluctuations in hormonal secretions in the female body coupled with accompanied changes in women female learners are not deficient in their ability in Physics. Trisma $\&$ J osiah (2008) also found out that achievement in Physics is not affected by gender.

In Nigeria, stereotyping rare its head in childrearing practices and societal expectations. These factors are perceived to inhibit the female gender from studying Physics. In the course of primary socialization process in the country, female children are protected and discouraged from engaging in explorative and risk-taking activities. The boys engage in activities that involve physical strength, challenging their mental power, their power of imagination and ingenuity. The girls, on the other hand, play with toys at home and assist in cooking food in the kitchen. It is such activities that the boys engage in that serve as building block for learning Physics in schools.

The society perceives Physics as a masculine subject. It expects women to operate in the home, keeping the house tidy and cooking food for the family. Okeke (2001) supplemented that marriage, bearing and rearing children are considered central in the role expectations for Nigerian women. Nigerian women must then have to fit into such stereotypes, constructed for them by the society in other to be accepted. They prefer to ignore Physics, other science subjects and sciencerelated subjects.

Religious beliefs in Nigeria are known to hinder the female gender from studying Physics. In fact, in some contemporary Nigerian regions, female education is still regarded as a taboo. Women are given out in marriage very early in life, and once married they are restricted to the house. Even if a female child nurses the intention of studying Physics, she may be hindered by such beliefs.

\section{Recommendations}

- Parents and the society should be sensitized on the need to change their attitudes on upbringing of children. Stereotyping must, indeed, be stopped if the female gender underrepresentation is to be addressed.

- Religious beliefs which are anti-female and anti-western education should be discouraged. 
- Women, themselves, need to be counseled by government and the few female Physics teachers on the beauty of studying Physics.

\section{Conclusion}

In view of the fact that the importance of Physics as a requirement for the socio-economic growth of any nation cannot be under-estimated, the female gender in Nigeria should be encouraged to take up Physics as a course of study in schools. By so doing the gender gap in existence will be drastically reduced, if not eliminated; the female gender would also be seen to be contributing its quota to the socio-economic development of the country, through science and technology.

\section{References}

Gonzuk, J.N. \& Chagok, M (2001). Factors that discourage girls from taking Physics- A case study of Plateau state (p.352-355). In 0.0. Busari (Ed). Women in Science, Technology and Mathematics Education in Nigeria. I badan: Heinemann Educational Books (Nig) Plc.

Ibitoye, S.J. (1998). Gender differences and achievement in secondary school Agricultural science in Kwara state. The Nigerian Teacher Today, 6(1).

I vowi, U.M.O \& Olodotun, J.S.O (2001). The status of women in Physics in Nigeria (p. 338-343). In 0.0. Busari (Ed). Women in science, Technology and Mathematics Education in Nigeria. Ibadan: Heinemann Educational Books (Nig) Plc.

John, S.M. \& Davou, G.M. (2008). Gender-based imbalance in women'srights issues and education in Nigeria (p. 386-393). In B.N.S Tang'an, N.E Arongol, H.O. Akalonu \& P.R Bedung (Eds). Coping with Global trends through Education. Mangu: Binachik printing press.

Nsofor, C.C (2001). Cultural impediments on women in science, technology and mathematics education (p. 48-51). In 0.0. Busari (Ed). Women in Science, Technology and Mathematics Education in Nigeria. I badan: Heinemann Educational Books (Nig) Plc.

Merriam-Webster Incorporated (2006). Webster's New Explorer Encyclopedia Dictionary. Massachusetts: Federal Street Press.

Ogunleye, A. (2001). Girl's perceptions of strategies for improving low enrolment, underachievement and attitudes of girls in Physics at the senior secondary school level (p.344-351). In 0.0. Busari (Ed). Women in Science, Technology and Mathematics Education in Nigeria. Ibadan: Heinemann Education Books (Nig) plc.

Ogunleye-Adetona, C.I. (2003). Gender issues and development: A welfaristic perspective. International Journal of Gender and Health Studies, 207-213.

Okeke, E. A, C. (2001). Women in science, technology and mathematics education in Nigeria (p.3-13). In O.O. Busari (Ed). Women in Science, Technology and Mathematics Education in Nigeria. Ibadan: Heinemann Educational Books (Nig) plc.

Onwuakpa, F.I.W. \& Akpan, B.B (2001). Some psycho-social issues on women in science, technology and mathematics education (STM) in Nigeria (p.95-99). In 0.0. Busari (Ed). Women in Science, Technology and Mathematics Education in Nigeria._Ibadan: Heinemann Educational Books (Nig) Plc.

Oyedokun, M.R. (2001). Female participation in science subjects in Nigerian Colleges of Education: Implications for science education (p.161-164). In 0.0. Busari (Ed). Women in Science, Technology and Mathematics Education in Nigeria. Ibadan: Heinemann Educational Books (Nig) Plc.

Trisma, E.A. \& J osiah, M.M. (2008). Coping with gender inequality in academic achievement in Physics in Federal College of Education, Pankshin. (p. 421-426). In B.N.S Tang'an, N.E Arongol, H.O. Akalonu \& P.R Bedung (Eds). Coping with Global trends through Education. Mangu: Binachik printing press. 
